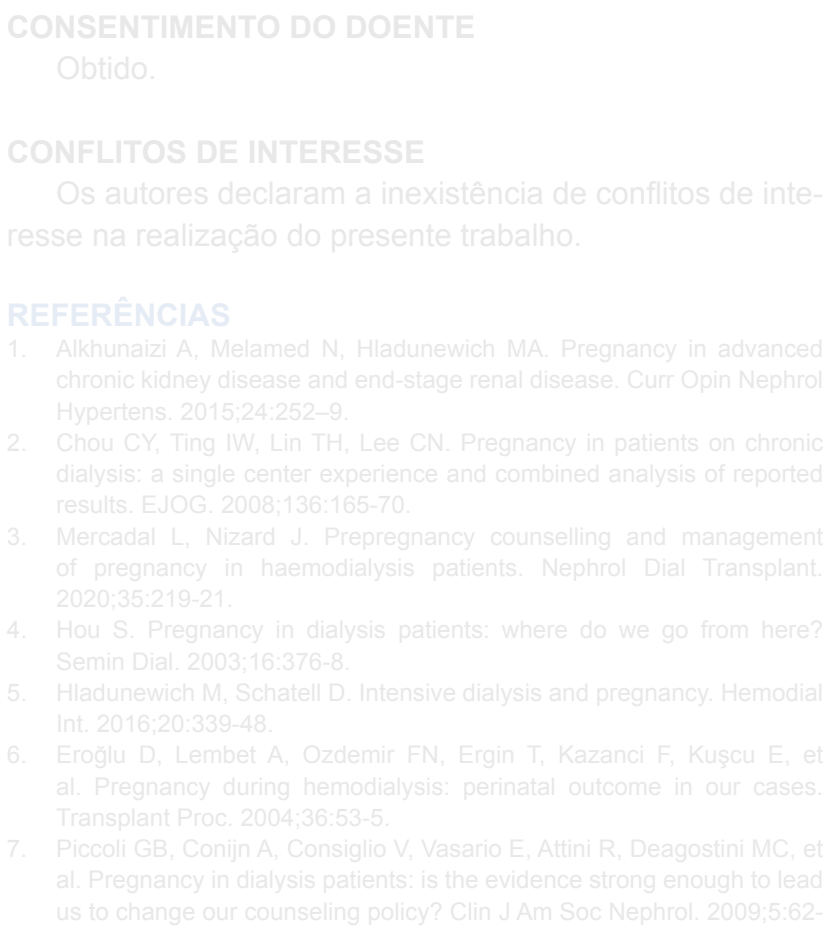

\title{
Photosensitive Self-Induced Seizures Since Childhood
}

\author{
Crises Epilépticas Auto-Induzidas Desde a Infância
}

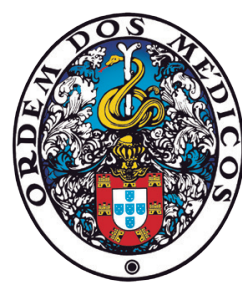

Eduardo PALHA-FERNANDES $\square^{1}$, Ariana TELES ${ }^{2}$, Amélia MENDES $^{3}$

Acta Med Port 2021 Jan;34(1):58-60 • https://doi.org/10.20344/amp.11677

\begin{abstract}
A 15-year-old girl was admitted to the emergency room because of a bilateral tonic-clonic seizure. The family reported that the episode began with rapid hand movements in front of the patient's eyes while staring at the sun. The patient has a history of multiple admissions in the emergency department due to similar events since the age of eight. Most occurrences were associated with episodes of frustration. The review of the literature has shown that this type of phenomenon, designated in some studies by sunflower syndrome, may be overlooked in patients with photosensitive epilepsy. Despite the unknown etiology, there are several reasons why patients experience this type of behavior, and thus a multidisciplinary approach is needed.
\end{abstract}

Keywords: Adolescent; Epilepsy, Reflex; Photic Stimulation; Seizures

\section{RESUMO}

Uma jovem de 15 anos foi admitida no Serviço de Urgência após ter sofrido crise epiléptica tónico-clónica bilateral. A família relatou que o episódio surgiu na sequência de ter iniciado movimentos rápidos das mãos na frente dos olhos enquanto olhava para o sol. $\mathrm{A}$ doente havia sido assistida, por diversas vezes, no Serviço de Urgência, devido a eventos semelhantes, desde os oito anos de idade. A maioria dos episódios estava associada a episódios de frustração. A revisão da literatura mostrou que esse tipo de fenómeno, designado em alguns estudos por sunflower syndrome, pode ser desvalorizado em doentes com epilepsia fotossensível. Apesar da etiologia desconhecida, existem várias razões pelas quais os doentes apresentam este tipo de comportamento, enfatizando a necessidade de uma abordagem multidisciplinar.

Palavras-chave: Adolescente; Convulsões; Epilepsia Reflexa; Estimulação Luminosa

\section{INTRODUCTION}

Self-induction is a type of seizure precipitation employed by patients to produce seizures on demand. ${ }^{1}$ Typically, patients will stare at a light source while waving their abducted fingers in front of their faces or will perform other behaviors that create a similar flickering effect. ${ }^{2}$ Seizures include eyelid myoclonia with or without absences seizures,

1. Departamento de Psiquiatria e Saúde Mental. Unidade Local de Saúde do Alto Minho. Viana do Castelo. Portugal.

2. Serviço de Pediatria. Unidade Local de Saúde do Alto Minho. Viana do Castelo. Portugal.

3. Unidade de Neurologia. Unidade Local de Saúde do Alto Minho. Viana do Castelo. Portugal.

$\triangle$ Autor correspondente: Eduardo Palha-Fernandes. eduardopalhafernandes@gmail.com

Recebido: 13 de dezembro de 2018 - Aceite: 18 de junho de 2019 | Copyright $\odot$ Ordem dos Médicos 2021 
even though some patients can go on to have generalized tonic-clonic seizures. ${ }^{3}$

\section{CASE REPORT}

A 15-year-old girl was admitted to the emergency room (ER) due to a seizure event. It was a self-induced episode of photo-stimulus where the patient stared at the sun while rapidly moving her fingers in front of her eyes. It was then followed by myoclonus-like body movements, and loss of consciousness with open eyes and sialorrhea.

The family reported that at the age of eight, she developed the habit of watching television extremely close to the screen. They further state that one time she lost vision bilaterally for a few seconds and recovered spontaneously. Neurological and ophthalmological examinations were normal. Within the same setting, she has presented similar responses of exaggerated opening of eyes, deviation of the gaze to one side and repetitive movement of the hand in front of her eyes. The patient has no recollection of these behaviors.

Six months after the first ER admission, she had an episode described as a tonic-clonic seizure with postictal vomiting, tongue bite and occipital trauma. She underwent a cranial computed tomography scan, which was unremarkable. The patient was prescribed an antiepileptic drug (clinical records not accessible) and did not develop new seizures for three years.

At twelve years old she had a new generalized seizure which resulted in head injury and abrasive skin lesions. Valproate was initiated $(20 \mathrm{mg} / \mathrm{kg}$ ). Her grandmother revealed that the seizure appeared after the patient waved one hand before her eyes during an anxiety episode. Following this event, the patient had four similar ER admissions within two years. She was referred for psychiatric consultation.

The patient and her relatives associated the seizures with episodes of frustration or attention-seeking. She reported that she felt bound to trigger photostimulation, especially on sunny days. Those maneuvers did not always trigger a seizure, but sometimes, she needed to repeat the movement several times during the day for a seizure to develop. She could not trigger a seizure with artificial light, only using sunlight. She denied non-induced seizures. There was no family history of epilepsy or relevant chronic diseases.

A brain magnetic resonance imaging scan was performed. It did not reveal any structural abnormalities. The patient also underwent an electroencephalogram (EEG) with intermittent light stimulation. Results were normal. The cognitive evaluation disclosed a lower than average IQ (72), and a discrepancy between verbal and performance intellectual quotients; major impairments were apparent in similarities, vocabulary and comprehension tests.

\section{DISCUSSION}

Self-induced photosensitive epilepsy is a rare condition. ${ }^{3}$ Literature is scarce, but in some studies this type of phenomenon is designated by sunflower syndrome. ${ }^{2}$ It may be undervalued in patients with photosensitive epilepsy. ${ }^{4,5}$
Since the first case reported in $1932,{ }^{6}$ some authors ${ }^{7-10}$ tried to estimate the prevalence of this phenomenon which remains extremely variable, and is mostly due to case detection differences. ${ }^{11}$

More recently, in Panayiotopoulos's ${ }^{2}$ experience of 442 patients with an onset of nonfebrile seizures from age 0 through 15 , only five $(1.3 \%)$ had self-induced seizures. The same author estimated that the age of onset ranges from infancy to mainly early childhood and has a $70 \%-80 \%$ female predominance. Despite the unknown etiology, $\mathrm{Ng}^{11}$ describes several reasons why patients may have this type of behavior - compulsion, willful avoidance of stress or escape from unpleasant situations or boredom, hedonistic motivations, need to obtain a sense of control (mastery) over the seizures, attention-seeking, or self-treatment.

Unlike our reported case, patients do not usually evolve to generalized tonic-clonic seizures and EEG abnormalities can be found..$^{2,3}$ Baumer $^{3}$ indicates valproate monotherapy as the most effective treatment for self-induced photosensitive epilepsy. This drug did not prevent our patient from performing the hand movements or having seizures. As shown in this case report, this condition seems to be notoriously resistant to therapy. ${ }^{12,13}$ The additional association with psychiatric factors justified the importance of a neuropsychiatric multidisciplinary approach.

One of the main obstacles to diagnose self-induction in photosensitive patients is that self-inducing patients are usually embarrassed to admit it. It sometimes requires longterm video-EEG monitoring as self-induction may occur after the technician leaves the room. ${ }^{14}$ This difficulty has led to some discussion on whether patient's hand waving is an attempt to induce flickering or a feature of the seizure itself. ${ }^{15}$ Although Panayiotopoulos ${ }^{1}$ speculates that both can happen, our case study shows that the first hypothesis seems definitely true. Our findings rely on our patient's willingness to discuss her habit.

\section{PROTECTION OF HUMANS AND ANIMALS}

The authors declare that the procedures were followed according to the regulations established by the Clinical Research and Ethics Committee and to the Helsinki Declaration of the World Medical Association.

\section{DATA CONFIDENTIALITY}

The authors declare having followed the protocols in use at their working center regarding patients' data publication.

\section{INFORMED CONSENT}

Obtained.

\section{CONFLICTS OF INTEREST}

All authors report no conflict of interest.

\section{FUNDING SOURCES}

The authors declare that there were no external sources of study for the performance of this article. 


\section{REFERENCES}

1. Panayiotopoulos CP. A clinical guide to epileptic syndromes and their treatment. London: Springer Science \& Business Media Ltd; 2010.

2. Ames FR, Saffer D. The sunflower syndrome: a new look at "selfinduced" photosensitive epilepsy. J Neurol Sci. 1983;1;59:1.

3. Baumer FM, Porter BE. Clinical and electrographic features of sunflower syndrome. Epilepsy Res. 2018;142:58-63.

4. Binnie CD, Darby CE, De Korte RA, Wilkins AJ. Self-induction of epileptic seizures by eyeclosure: incidence and recognition. J Neurol Neurosurg Psychiatry. 1980;43:386-9.

5. Darby CE, Korte RA, Binnie CD, Wilkins AJ. The self-induction of epileptic seizures by eye closure. Epilepsia. 1980;1;21:31-42.

6. Radovici A. Epilepsie reflexe provoquee par excitations optiques des rayons solaires. Rev Neurol. 1932;1:1305.

7. Antebi D, Bird J. The facilitation and evocation of seizures. A questionnaire study of awareness and control. Br J Psychiatry. 1993;162:759-64.

8. Zifkin B, Andermann F, Rowan AJ, Beaumanoir A, editors. Reflex epilepsies and reflex seizures. New York: Lippincot-Raven; 1998.

9. Kasteleijn-Nolst DT. Photosensitivity in epilepsy. Electrophysiological and clinical correlates. Acta Neurol Scand. 1989;125:S3-149.

10. Jeavons PM. Photosensive epilepsy: a review of the literature and a study of 460 patients. London: Heinemann; 1975.

11. Ng BY. Psychiatric aspects of self-induced epileptic seizures. Aust N Z J Psychiatry. 2002;1;36:534-43.

12. Ames FR, Enderstein $O$. Clinical and EEG response to clonazepam in four patients with self-induced photosensitive epilepsy. S Afr Med J. 1976;50:1432-4.

13. Rail LR. The treatment of self-induced photic epilepsy. Proc Aust Assoc Neurol. 1973;9:121-3.

14. Kasteleijn-Nolst Trenité DG. Provoked and reflex seizures: surprising or common? Epilepsia. 2012;1;53:S105-13.

15. Livingston S, Torres IC. Photic epilepsy: report of an unusual case and review of the literature. Clin Pediatr. 1964;3:304-7. 